\title{
FERMENTASI OHMIC KOPI HS BASAH TERHADAP AROMA DENGAN PENAMBAHAN ENZIM BROMELIN
}

\author{
Henny Poerwanty ${ }^{1)}$, Erna Halid ${ }^{1)}$ \\ Department Budidaya tanaman Perkebunan, Pangkep State Polytechnic of Agriculture, Pangkep, \\ South Sulawesi, Indonesia \\ Email: hpoerwanty@gmail.com
}

\begin{abstract}
ABSTRAK
Penelitian ini bertujuan : (1) mengetahui pengaruh suhu dan lama fermentasi (2) mengetahui pengaruh enzim bromelin terhadap aroma biji kopi. Proses fermentasi biji kopi menggunakan teknologi ohmic dengan penambahan ekstrak nanas. Perlakuan yang digunakan pada fermentasi dengan teknologi ohmic yaitu suhu $\left(35^{\circ} \mathrm{C}\right.$ dan $\left.45^{\circ} \mathrm{C}\right)$ dan lama fermentasi $(6,12$, dan 18 jam). Parameter pengamatan meliputi $\mathrm{pH}$, kandungan kafein, dan organoleptik. Berdasarkan hasil penelitian didapatkan bahwa pada fermentasi biji kopi dengan teknologi ohmic pada suhu $35^{\circ} \mathrm{C}$ dan lama fermentasi 12 jam mendapatkan kadar kafein $(1,6 \%)$ menjadi $(0.047 \%)$ dan pada suhu $35^{\circ} \mathrm{C}$ dan lama fermentasi 12 jam didapatkan nilai $\mathrm{pH}$ (4.81). Sedangkan pada suhu $45^{\circ} \mathrm{C}$ dengan lama fermentasi 6 jam mendapatkan nilai kafein yang tinggi yaitu $(0.147 \%)$ dan pada suhu $45^{\circ} \mathrm{C}$ dengan lama fermentasi 18 jam didapatkan nilai $\mathrm{pH}(5,83)$. Deskripsi organoleptik pada atribut aroma dengan suhu $35^{\circ} \mathrm{C}$ dan lama fermentasi 12 jam mendapatkan rata-rata skor pada fruity (3.96), caramel (4.52) dan chocolate (3.82) sedangkan pada suhu $45^{\circ} \mathrm{C}$ dan lama fermentasi 12 jam mendapatkan rata-rata skor pada fruity (3.26), caramel (4.16) dan chocolate (4.16). Deskripsi organoleptik pada atribut rasa suhu $35^{\circ} \mathrm{C}$ dan lama fermentasi 12 jam mendapatkan rata-rata skor body (4.94) dan bittness $(3,7)$ dan pada suhu $45^{\circ} \mathrm{C}$ dan lama fermentasi 12 jam mendapatkan rata-rata skor body (3.49) dan bittness (3.49). Fermentasi biji kopi dengan teknologi ohmic sangat efektif digunakan karena dapat memberikan sistem pemanasan yang relatif seragam dan merata.
\end{abstract}

Kata kunci: Fermentasi, Kopi, pH, Suhu, Teknologi ohmic, dan Waktu

\begin{abstract}
This study aimed (1) to determine the effect of temperature, and (2) to determine the fermentation time and the effect of bromelin enzyme of coffee beans aroma. The process of fermentation of coffee beans using the ohmic technology with the addition of pineapple extract. The treatment used in the fermentation with Ohmic technology was the temperatures of $35^{\circ} \mathrm{C}$ dan $45^{\circ} \mathrm{C}$ and fermentation times were 6,12 , and 18 hours. The observation parameters included $\mathrm{pH}$, caffeine content, and organoleptics. The research results indicated that in the fermentation of the coffee beans using Ohmic technology at temperature of $35^{\circ} \mathrm{C}$ and the time fermentation of 12 hours, the caffeine content $(1.6 \%)$ became $0.047 \%$, and the temperature of $35^{\circ} \mathrm{C}$ and the time of fermentation was 12 hours had produced $\mathrm{pH}$ of 4.81 , and the temperature of $45^{\circ} \mathrm{C}$ with time fermentation of 6 hours, high caffeine value of $0.147 \%$, and at $45^{\circ} \mathrm{C}$ with the time fermentation of 18 hours had produces $\mathrm{pH}$ value of 5.83. The organoleptic description of the flavor attribute with temperature of $35^{\circ} \mathrm{C}$, the temperature flavor attribute and the time fermentation of 12 hours, the average body score was 4.94, and the bitterness was 3.7, and at the temperature of $45^{\circ} \mathrm{C}$ and the time fermentation of 12 hours produced the body weight scores of 3.49 , and the bittnerss of 3.45 . The fermented coffee beans with the clinical technology was
\end{abstract}


very effective to use because it could provide a relatively uniform and evenly distributed heating system.

Keywords: Fermentation, coffee, pH, Temperature, ohmic technology and Time.

\section{PENDAHULUAN}

Kopi merupakan tanaman perkebunan yang memiliki nilai ekonomis yang tinggi. Kopi tidak hanya berperan sebagai sumber devisa tetapi juga sumber penghasilan bagi lebih dari satu setengah juta petani kopi di Indonesia. Posisi Indonesia dinilai cukup strategis dalam sektor perkopian Internasional, karena Indonesia merupakan Negara pengekspor kopi terbesar ketiga setelah Brazil dan Vietnam (FAO, 2013). Produktivitas kopi Indonesia dari tahun 1980-2017 sebesar 637.539 ton per tahun. Jika pada tahun 1980 volume ekspor kopi Indonesia sebesar 238.677 ton dengan nilai ekspor sebesar US\$ 656 juta, maka tahun 2015 volume ekspor meningkat menjadi 502.021 ton atau senilai US\$1.198 juta Dirjen perkebunan (2016).

Kopi diolah dengan beberapa cara pengolahan yaitu cara basah dan cara kering. Salah satu tahapan pengolahan cara basah kopi arabika yang sangat menentukan mutu adalah fermentasi. Fermentasi bertujuan untuk menghilangkan lapisan lendir yang tersisa di permukaan kulit tanduk biji kopi setelah proses pengupasan. Akan tetapi, proses fermentasi yang terlalu lama akan menghasilkan kopi beras yang berbau apek karena terjadi pemecahan komponen isi lembaga (Ciptadi \& Nasution, 1985).

Fermentasi terkendali dengan menggunakan fermentor dilakukan untuk mengontrol suhu selama proses fermentasi. Teknologi fermentasi ini dapat dikombinasikan dengan penambahan mikroorganisme/enzim ataupun tanpa mikroorganisme (Yusianto et al., 2013). Menurut Yusianto et al., (2013), penelitian ini menggunakan double jacketed tank sebagai fermentor. Pemanasan Fluida dilakukan dengan menggunakan pemanas listrik. Suhu fluida pemanas sangat berfluktuasi sehingga suhu biji kopi dalam fermentor juga berfluktuasi. Dalam penelitian ini, fermentasi biji kopi dilakukan dengan menggunakan pemanasan ohmic. Teknologi ini membangkitkan panas secara internal sehingga proses pemanasan berlangsung secara tepat dan seragam, serta mudah dikontrol secara akurat (Salengke, 2002).

Proses fermentasi yang dilakukan dalam penelitian menggunakan penambahan enzim bromelin yang berasal dari Nanas (Ananas comosus L. Merr). Enzim ini mampu mempercepat proses pelepasan lendir dan memecahkan senyawa protein dan gel serta mampu menurunkan kadar kafein kopi menjadi lebih rendah (Oktadina et al., 2013). 
Mengacu pada uraian diatas maka perlu diadakan penelitian mengenai proses fermentasi dengan menggunakan teknologi ohmic dan penambahan enzim bromelin. Parameter perlakuan yang perlu dipelajari meliputi lama dan suhu fermentasi serta pengaruhnya terhadap kopi.

\section{BAHAN DAN METODE}

Kegiatan utama dalam penelitian ini yaitu melakukan fermentasi biji kopi pada teknologi ohmic dengan penambahan ekstrak nanas dengan dua faktor pengamatan yaitu lama fermentasi $(6,12,18$ jam $)$ dan suhu $\left(35^{\circ} \mathrm{C}\right.$ dan $\left.45^{\circ} \mathrm{C}\right)$. Tahap kedua penelitian ini dirancang dalam percobaan factorial menggunakan rancangan acak lengkap dengan tiga kali pengulangan. Uji organoleptik dengan metode QDA merupakan suatu metode yang didasarkan atas tingkat kesukaan panelis terhadap sampel yang disajikan dengan melibatkan tujuh orang panelis. Uji dengan metode ini biasanya digunakan untuk mengukur tingkat penerimaan konsumen akan produk yang ditawarkan. Jenis pengujian yang dilakukan dalam uji organoleptik ini adalah metode tingkat kesukaan terhadap aroma dan rasa dengan skor 0-7. Penelitian ini dirancang dalam percobaan faktorial menggunakan rancangan acak lengkap dengan tiga kali pengulangan dengan metode analisis varians menggunakan Statistic Package for Social Sciene (SPSS). Bila hasil dari analisis sidik ragam memperlihatkan pengaruh nyata $(\alpha=0,05)$ maka dilakukan uji beda nyata dengan menggunakan uji beda jarak berganda Duncan. Analisis varians (ANOVA) diterapkan untuk menentukan efek utama dari factor Independen yang diteliti (persentase aroma dan rasa) terhadap atribut sensorik sebagaimana yang dinilai panelis selama prosedur QDA.

\section{HASIL DAN PEMBAHASAN}

Uji organoleptik dilakukan dengan tujuan untuk mengetahui tingkat kesukaan panelis terhadap produk yang dihasilkan. Panelis diminta memberikan skor 0-7 berdasarkan tingkat kesukaan.

Tabel 1 memperlihatkan bahwa hasil cuptest nilai aroma yang terbaik pada suhu $35^{\circ} \mathrm{C}$ dan lama fermentasi 6 jam mendapatkan nilai tertinggi burnt $(6,27)$ dan atribut caramel dan fruity pada suhu $35^{\circ} \mathrm{C}$ dan lama fermentasi selama 12 jam yaitu (5.85) dan (5.83). Sedangkan fermentasi pada suhu $45^{\circ} \mathrm{C}$ dan lama 6-12 jam mendapatkan nilai terendah pada atribut Caramel (2.85) dan Fruity (2.50).

Gambar 1 menunjukkan pada perlakuan fermentasi dengan suhu $35^{\circ} \mathrm{C}$ dan lama 6 jam memiliki nilai burnt yang tinggi. Selanjutnya pada fermentasi dengan suhu $35^{\circ} \mathrm{C}$ dan 12 jam memiliki aroma fruity, caramel, dan chocolate. 
Tabel 1. Hasil analisis uji sensory taste aroma berdasarkan suhu dan waktu pada fermentasi biji kopi

\begin{tabular}{ccccc}
\hline \multicolumn{2}{c}{ Perlakuan } & \multicolumn{3}{c}{ Atribut } \\
\hline Suhu ${ }^{\circ} \mathrm{C}$ & Waktu(jam) & Chocolate & Caramel & Fruity \\
\hline \multirow{3}{*}{35} & 6 & 3,16 & 3,99 & 2,89 \\
& 12 & 4,87 & 5,85 & 5,83 \\
& 18 & 3,44 & 3,71 & 3,16 \\
45 & 6 & 4,04 & 3,31 & 2,50 \\
& 12 & 4,63 & 2,85 & 2,94 \\
& 18 & 3,80 & 3,34 & 4,34 \\
\hline
\end{tabular}

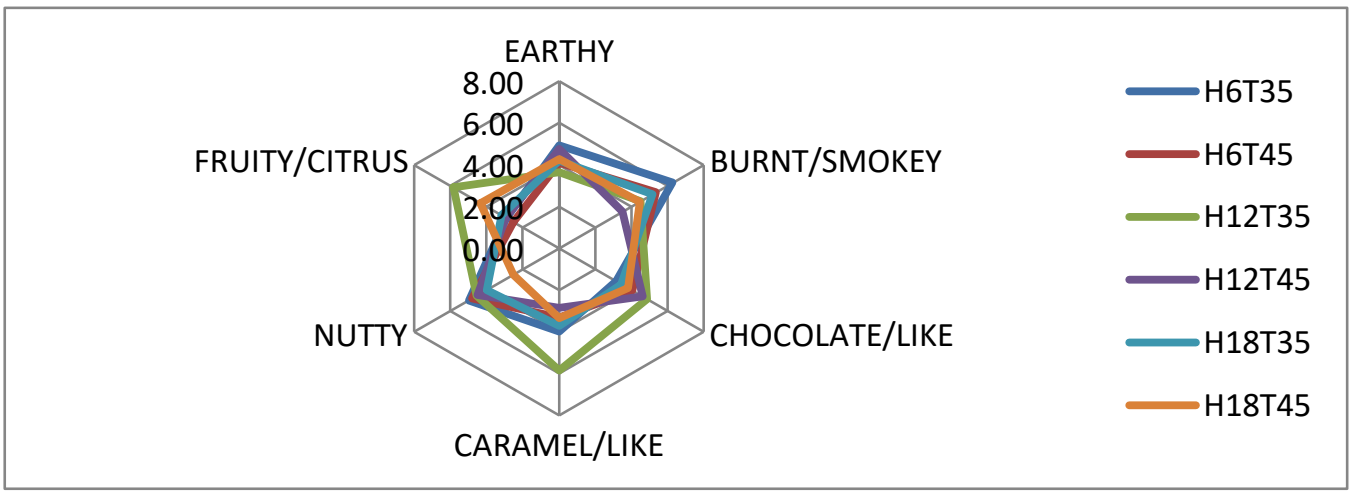

Gambar 1. Profil aroma fermentasi kopi dengan perlakuan suhu dan waktu

Tabel 2 memperlihatkan bahwa hasil cuptest nilai atribut rasa yang terbaik pada suhu $35^{\circ} \mathrm{C}$ dengan lama fermentasi 18 jam yang memiliki nilai body tinggi (5.80) sedangkan nilai body rendah $(2,17)$ pada suhu $45^{\circ} \mathrm{C}$ dengan lama fermentasi 6 jam

Tabel 2. Hasil analisis uji sensory taste rasa berdasarkan suhu dan waktu pada fermentasi biji kopi

\begin{tabular}{cccc}
\hline Perlakuan & \multicolumn{3}{c}{ Atribut } \\
\hline Suhu $^{\circ} \mathrm{C}$ & Waktu(jam) & Sourness & Body \\
\hline & 6 & 2,91 & 4,43 \\
35 & 12 & 4,57 & 4,59 \\
& 18 & 4,40 & 5,80 \\
& 6 & 4,84 & 2,17 \\
45 & 12 & 3,34 & 2,77 \\
& 18 & 4,34 & 5,53 \\
\hline
\end{tabular}

Gambar 2 menunjukkan bahwa pada perlakuan suhu yang sama yaitu suhu $35^{\circ} \mathrm{C}$ dan lama fermentasi 6 jam dan 18 jam mendapatkan nilai body $(5,80)$ dan nilai bittness $(4,37)$. Penilaian karakteristik kopi secara organoleptik meliputi penilaian biji beras, biji hasil sangrai, dan seduhan. Penilaian terhadap karakter biji kopi beras dan biji hasil sangrai belum dapat 
menggambarkan karakteristik suatu kopi sesungguhnya sehingga biasanya hanya digunakan sebagai pelengkap dari penilaian cita rasa seduhan (Lingle, 2011).

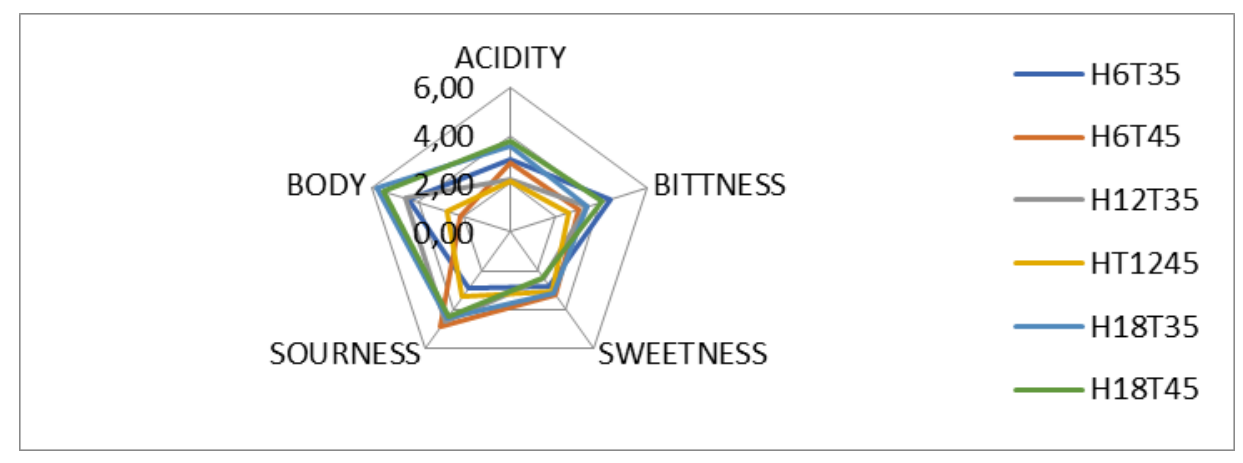

Gambar 2. Profil rasa fermentasi kopi dengan perlakuan suhu dan waktu

Dalam penelitian ini terlihat suhu dan lama fermentasi sangat mempengaruhi aroma pada kopi. Menurut Reta et al., (2017), yang menyatakan bahwa citarasa kopi yang terbaik berlangsung selama fermentasi 12 jam dengan suhu $35^{\circ} \mathrm{C}$ menghasilkan citarasa terbaik pada flavor, aroma dan balance. Jika suhu kurang dari $30^{\circ} \mathrm{C}$ pertumbuhan mikroorganisme penghasil asam akan lambat sehingga dapat merusak produk. Proses fermentasi yang tidak tepat akan menghasilkan biji kopi dengan citarasa yang rendah. Dimana hal ini juga merupakan suatu keunggulan citarasa yang dihasilkan pada fermentasi ohmic dengan suhu dan lama fermentasi yang terkontrol sehingga panas yang ditimbulkan oleh ohmic akan menyebar dengan baik pada semua permukaan bahan yang akan difermentasi, dibandingkan dengan fermentasi yang terjadi pada luwak. Proses fermentasi dapat dapat memacu terjadinya proses kimiawi yang sangat berguna dalam pembentukan precursor citarasa biji kopi, yaitu asam organic, asam amino, dan gula reduksi (Lin, 2010).

Kadar kafein yang rendah menakibatkan nilai body rendah pula. Menurut Yusianto et al., (2013), yang menyatakan bahwa body merupakan kekentalan dari seduhan kopi sebagai karakter internal yang dapat dinilai karena ada kesan kental di langit-langit mulut. Kafein memberikan kontribusi pada body seduhan kopi. Hal ini dapat diselaraskan dengan kadar kafein kopi bubuk yang semakin menurun akan berpengaruh pada nilai body yang semakin rendah. Sensasi kekayaan tekstur dan rasa menunjukkan nilai body dari kopi. Dengan demikian semakin lama waktu fermentasi akan menghasilkan kopi seduhan akhir semakin pahit. Menurut Reta et al.,(2017) yang menyatakan bahwa bittness merupakan rasa pahit yang akan menjadi ciri khas kopi. Pada tingkat rendah, rasa pahit membantu mengurangi keasaman kopi dan menambah dimensi rasa minuman. Namun pada tingkat tinggi, senyawa yang menimbulkan rasa pahit kopi dapat mengalahkan komponen rasa yang lain. 


\section{KESIMPULAN}

Berdasarkan penelitian yang telah dilakukan bahwa fermentasi biji kopi yang dilakukan dengan suhu $35^{\circ} \mathrm{C}$ selama 12 jam memberikan hasil yang terbaik yaitu mampu menurunkan kafein $(1,6 \%)$ menjadi $(0.047 \%)$ dan mendapatkan nilai $\mathrm{pH}$ 4.81. Karakteristik aroma dan rasa pada fermentasi dengan penambahan enzim bromelin mendapat respon terbaik dengan nilai tertinggi dari panelis pada uji organoleptik dengan deskripsi aroma fruity, caramel, dan chocolate sedangkan pada rasa memiliki body dan bittness yang sangat tinggi. Selain itu, Perlu dilakukan lebih lanjut lagi fermentasi kopi dengan teknologi ohmic dengan penambahan ekstrak nanas pada berbagai macam konsentrasi dan varietas kopi.

\section{UCAPAN TERIMA KASIH}

Dismapaikan terima kasih dan penghargaan kepada Direktorat Jenderal Pendidikan Vokasi, Kementerian Pendidikan dan Kebudayaan (Kemendikbud) yang telah mendanai penelitian ini.

\section{DAFTAR PUSTAKA}

Ciptadi W. \& Nasution M.Z. (1985). Pengolahan Kopi. Bogor: Agro Industri Press

Dirjen Perkebunan. (2016). Statistik Perkebunan Indonesia Kopi 2015-2017. Jakarta

Food and agriculture organization of United Nation (FAO). (2016). http://faostat.fao.org [terhubung berkala]

Lin C.C. (2010). Approch of Improving Coffee Industry in Taiwan Promote quality of Coffee bean by fermentation. The journal of Internasional management Studies5(1) ; 154159

Lingle T.R. (2011). The Coffee Cupper's Handbook: Asystematic Guide to the Sensory Evaluation Of Coffee's

Oktadina F.D., Argo B.D., \& Hermanto M.B. (2013). Pemanfaatan Nanas (Annanas Comosus L. Merr) untuk Penurunan Kadar Kafein dan Perbaikan Cita Rasa Kopi (Coffea sp) dalam Pembuatan Kopi Bubuk. Jurnal Keteknikan Pertanian Tropis dan Biosistem. Vol. 1, No. 3

Reta, Mursalim, Muhidong J., \& Salengke. (2017). Characteristic Flavour of Robusta Coffee from South Sulawesi after Fermentation by Ohmic Technology. International Journal of Current Research in biosciencesand plant biology. Vol 4 Number 7

Salengke S. (2002). Electrothermal Effects of Ohmic Heating on Biomaterials. Ph.D. Dissertation, The Ohio State University, Columbus, $\mathrm{OH}$.

Soekarto S.T. \& Hubeis M. (1993). Metodologi Penelitian Organoleptik. Program Studi Ilmu Pengan, IPB, Bogor. 
Yusianto, Hulupi R., Sulistyowati, Mawardi S., \& Ismayadi C. (2013). Pengolahan dan komposisi kimia biji kopi dan pengaruhnya terhadap citarasa seduhan. Warta Pusat penelitian Kopi dan Kakao, 15.190-202. 